\title{
ACTIVE FAULTS AND CHARACTERIZATION IN OSAKA AND ALMATY BY BORING DATA BASE
}

\author{
Yoshinori Iwasaki', Askar Zhussupbekov², Gulzhanat Tanyrbergenova ${ }^{3}$ \\ ${ }^{1}$ Geo Research Institute \\ 4-3-2, Itachibori, Nishi-ku, 550-0012, Osaka, Japan \\ 2,3 L.N.Gumilyov Eurasian National University \\ Satpayev Str. 2, Astana, Kazakhstan \\ ${ }^{1}$ yoshi-iw@geor.or.jp
}

\section{Abstract}

The active fault in Osaka is known as Uemachi fault, which had been originally identified as geomorphological feature of the Osaka high terrace. However, the position of the fault line was corrected by geotechnical information during subway construction.

Later another active fault was identified by the continuous characteristics of geological formation which was later identified by seismic study.

Active fault lines in Almaty were identified based upon geomorphological feature and should be confirmed by underground information of boring data and seismic study.

Osaka and Almaty did not take any consideration of the active fault in the city except strong ground motions. In these cities, structural effects from fault displacements should be considered to not only independent buildings but also such lifelines of infrastructures of freeways, subway, and electric power as well gas lines. Especially, Almaty is the most dangerous situation. Geotechnical engineers in Kazakh should initiate the study of active fault and provide the damage potential and as well as effective countermeasures to protect the 1.5 million citizens in Almaty and to create resilient city.

\footnotetext{
Keywords

Boring data, active fault, hidden fault, Los Angeles, Osaka, Almaty.
}

\section{Introduction}

Basically active faults in Osaka area distribute along such lines of mountain foot as well as line of edges of terraces of recent young geological deposits. These are based upon geomorphological feature of the present mountains and terraces that have been made by fault movements as shown Figure 1.

In Figure 1, Uemachi fault is identified as the western edge of the Uemachi terrace in Osaka city. When a subway construction for Kintetsu-line that is crossing with the Uemachi-fault showed the geological section along the line as in Fig.2, it was found that the real fault is not on the edge of the terrace but some $500 \mathrm{~m}$ away to the west. The height of the western side of the ground is about $+10 \mathrm{~m}$ and that of the eastern side is about $+20 \mathrm{~m}$.
The difference of $10 \mathrm{~m}$ of the ground level had been considered as the fault displacement. In Fig.2, the boring samples were identified geological formation and shown as Ma number. Ma stands for marine clay deposit. The formation of Ma11 is found at the level of $-15 \mathrm{~m}$ in the western side and $+10 \mathrm{~m}$ in the eastern side. The difference of $25 \mathrm{~m}$ is the fault displacement after the deposition of the Ma11 to the present time of about 210,000 years as shown in Table 1.

It is considered that the original cliff that had been created by the fault displacement was eroded away and the cliff was moved eastwards as shown at present. The return period of the Uemachi fault is estimated about 10,000 year. The anticipated vertical displacement for one fault movement is about $1.2 \mathrm{~m}$ as shown in Table 1. 


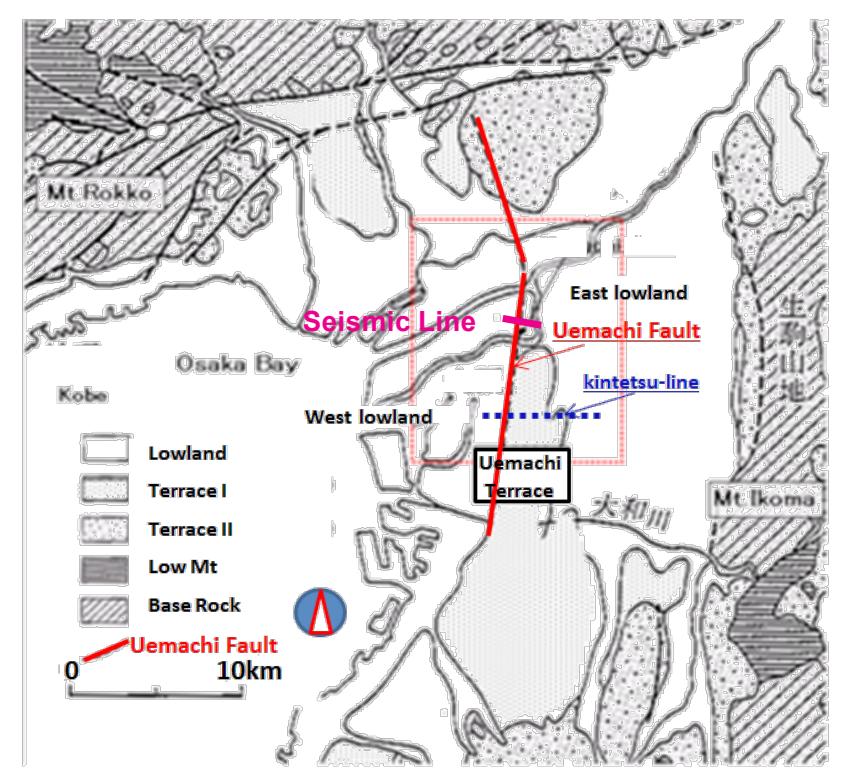

Figure 1. Uemachi fault identified along the edge of Uemachi terrace (1960)

A seismic reflection survey was performed along the seismic line in Fig.1. The result was shown in Figure 3. The underground feature of the fault was clearly identified by the reflection survey.

The depth of the base rock near the east and the west end of the surveyed line was about GL-800m and GL$1500 \mathrm{~m}$. The difference of the depths of the base rocks is considered as the fault movement in the past of 3 million years from present.
Table 1. Geological formation and deposited period

\begin{tabular}{|l|c|c|c|}
\hline Clay formation & $\begin{array}{l}\text { geologi- } \\
\text { cal age }\end{array}$ & \multicolumn{2}{l|}{ vertical dip displacement } \\
\cline { 2 - 4 } & (ka) & (total/m ) & (per event/m) \\
\hline Ma12 & 130 & & \\
\hline Ma11 & 210 & 25 & 1.2 \\
\hline Ma10 & 300 & & \\
\hline Ma9 & 380 & & \\
\hline Ma8 & 450 & & \\
\hline Ma7 & 540 & & \\
\hline Ma6 & 600 & & \\
\hline Ma5 & 660 & & \\
\hline
\end{tabular}

From the information of study of surface to underground

Fault map in Osaka was revised after the recognition of the geotechnical study along the subway line as shown in Figure 4. The Uemachi fault was shown westwards in the geological map in 1980. At the same time, two additional faults lines were added as Fault 2 and 3 . Fault 2 was estimated along the topological feature of the terrace in the south Osaka.

Fault 3 was estimated by not from surface topology but from the underground structure.

Geotechnical boring data system in Osaka began in 1980 and some special feature was recognized along the line of "Fault 3" in Figure 4.

\section{Topologically identified line of fault}

\section{Line of fault by underground boring}

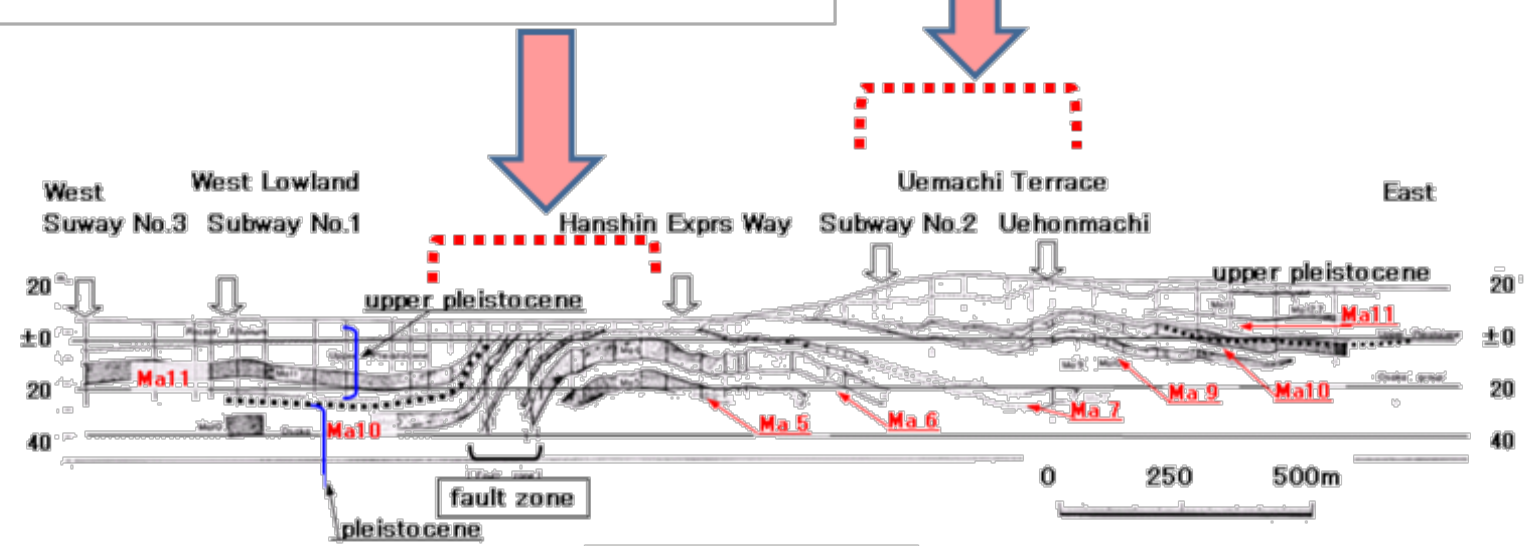

Figure 2. Underground structure along Kintetsu line 


\section{Architecture and Engineering Volume 3 Issue 2}

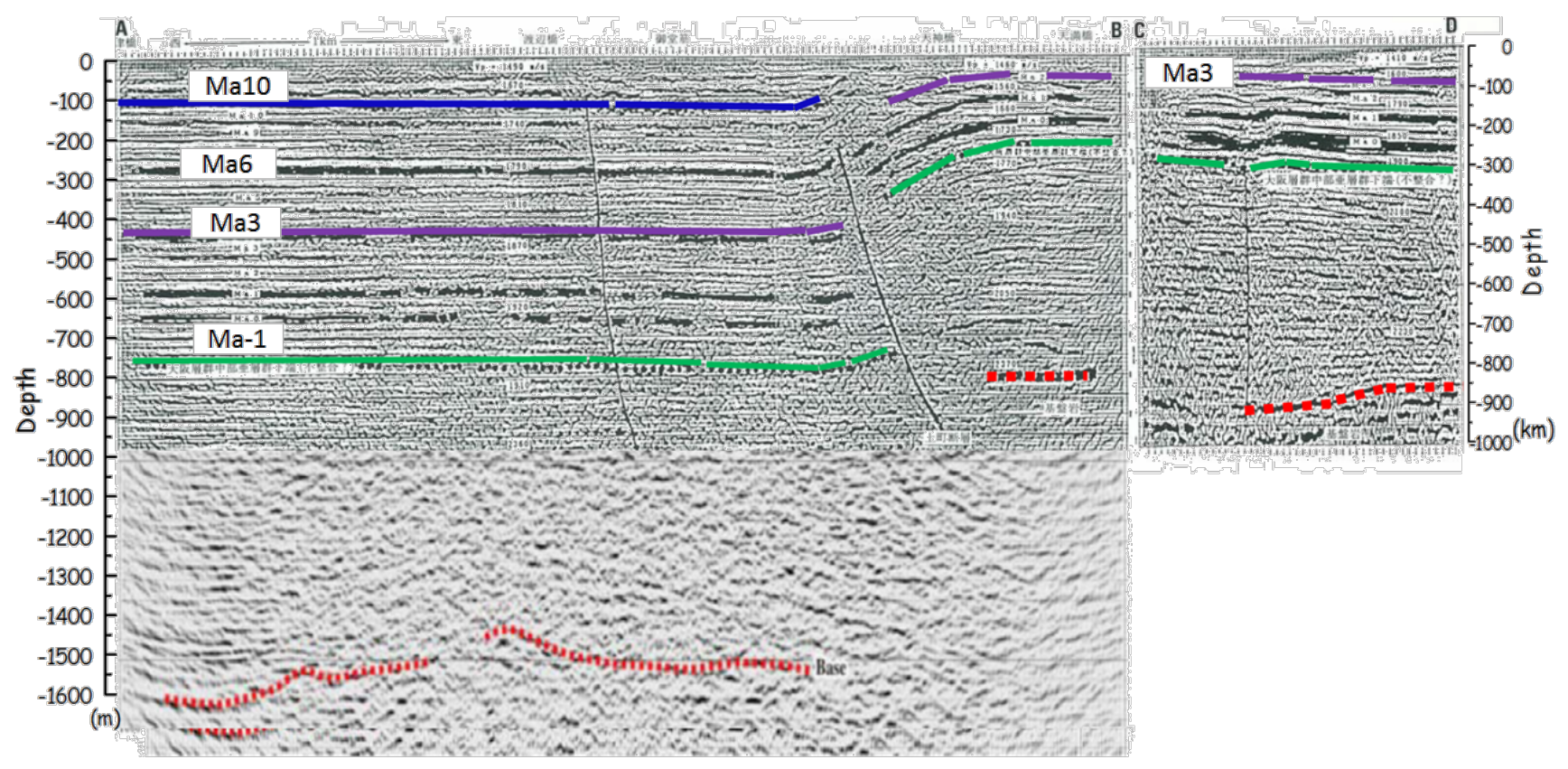

Figure 3. Nakanoshima seismic reflection line (1991)

Figure 4 shows a typical boring section along N-S line in Figure 3, where Ma13 of the recent deposit of clay layer is horizontal formation. Those layers of Ma11 and Ma10 are inclined towards north and the Ma12 is also inclined towards north but seems deposited horizontally at the north end. This unique combination of the horizontal layer of recent deposit with inclined formations of the earlier deposit was found along the fault line of "F3" in Figure 4.
After the Kobe earthquake of 1995, the author was asked where and how the fault should be studied in Osaka by the department of disaster prevention of Osaka city.

We recommended seismic reflection as well as deep boring including the line of N-S in Figure 5 . The result is shown in Figure 7. The geophysical result shows the underground structure that was expected by geological study based upon geotechnical database.

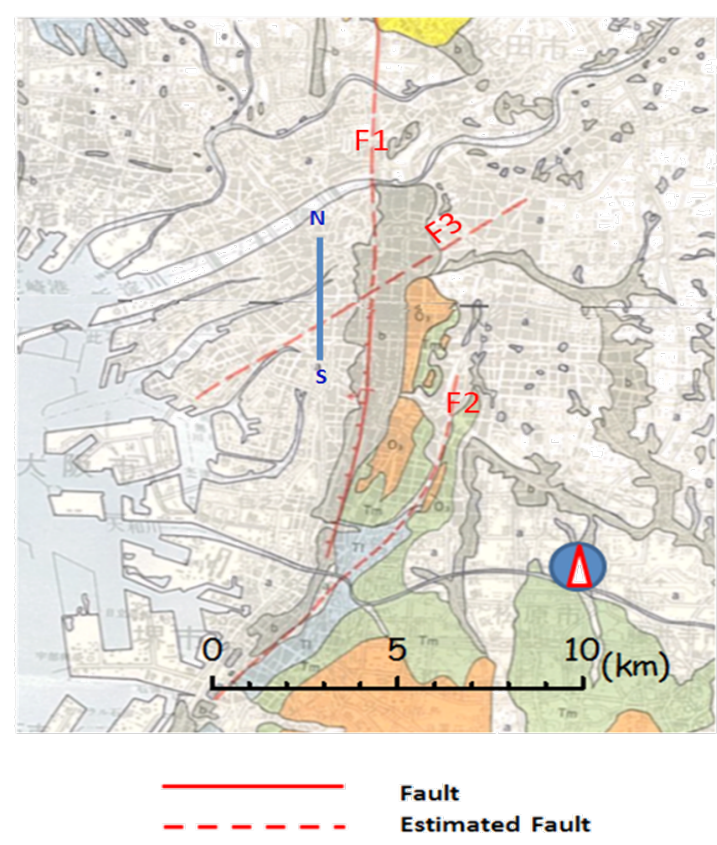

Figure 4. Fault map in Osaka in 1980

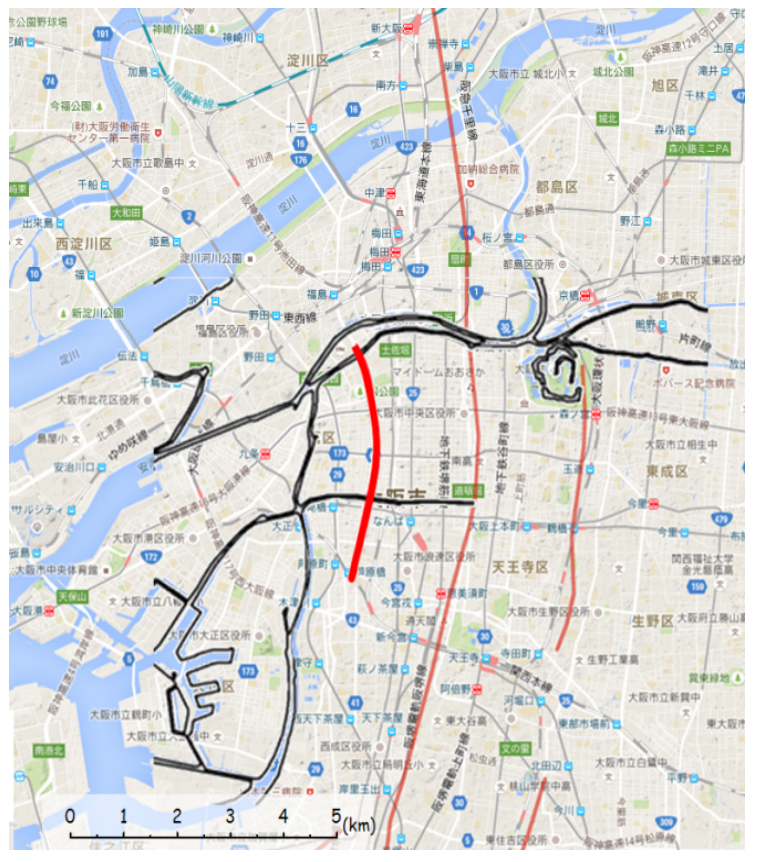

Figure 5. Seismic line along the fault 

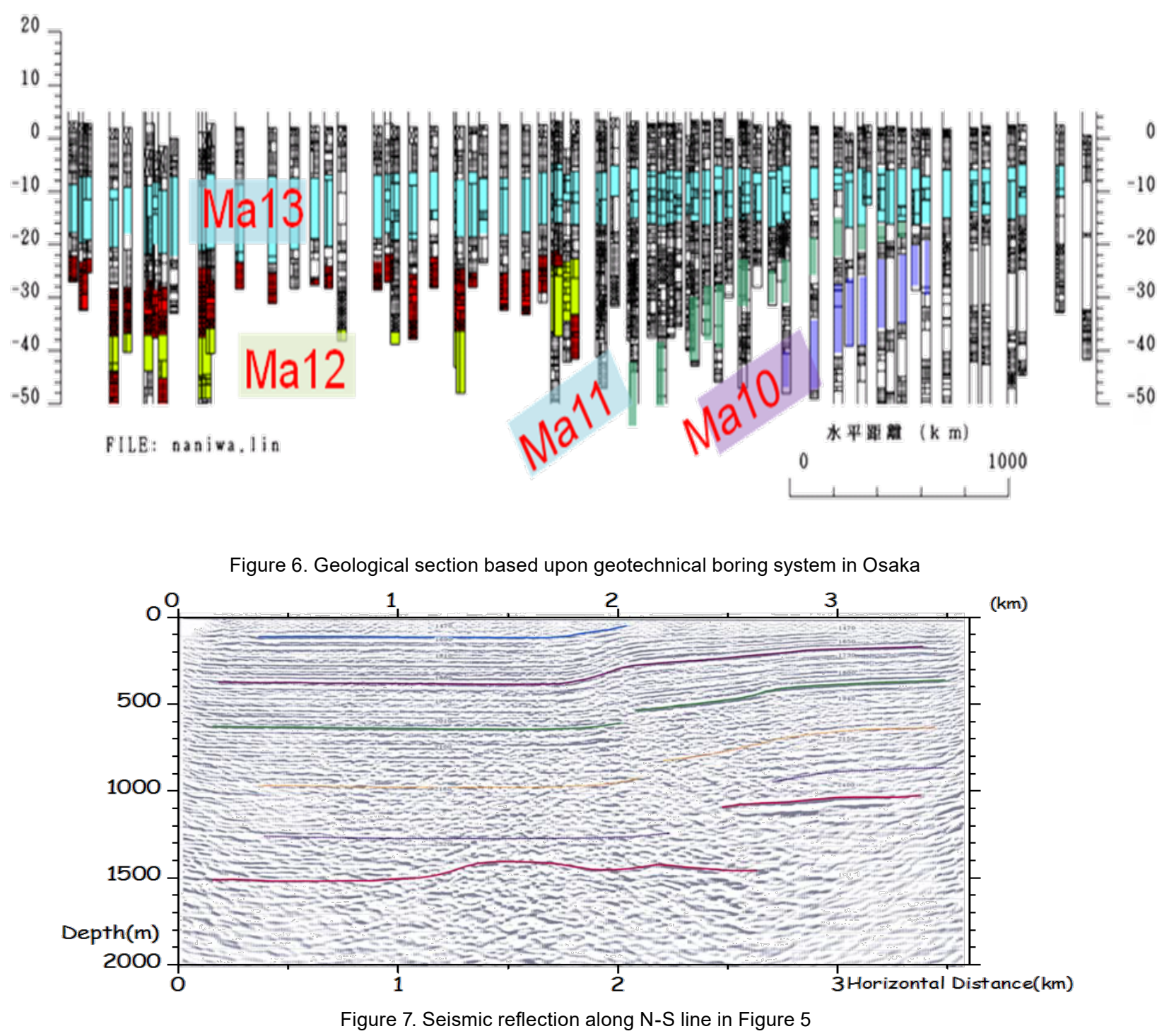

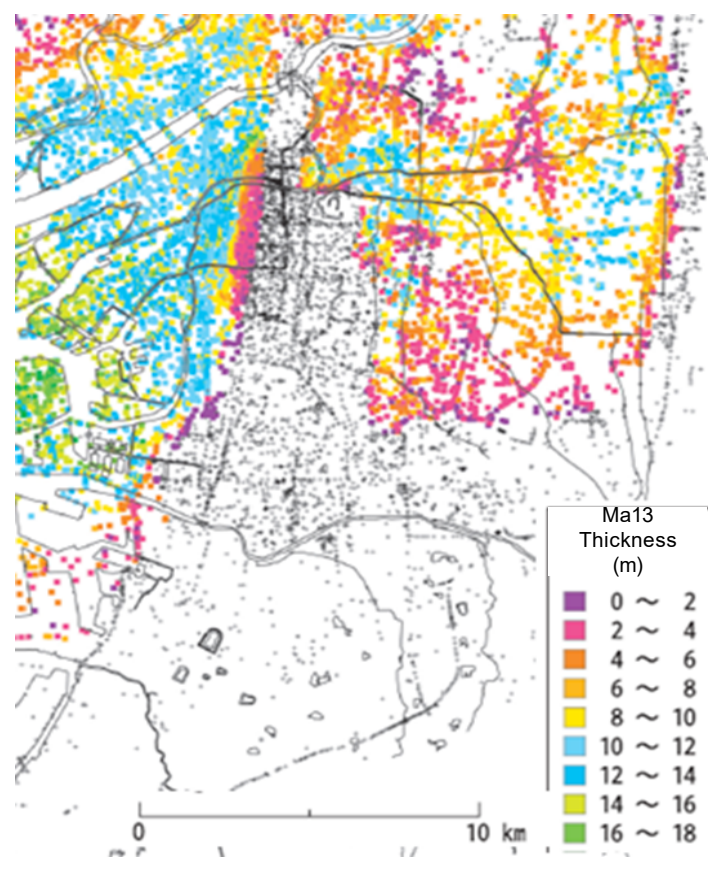

Figure 8. Thickness of Ma13

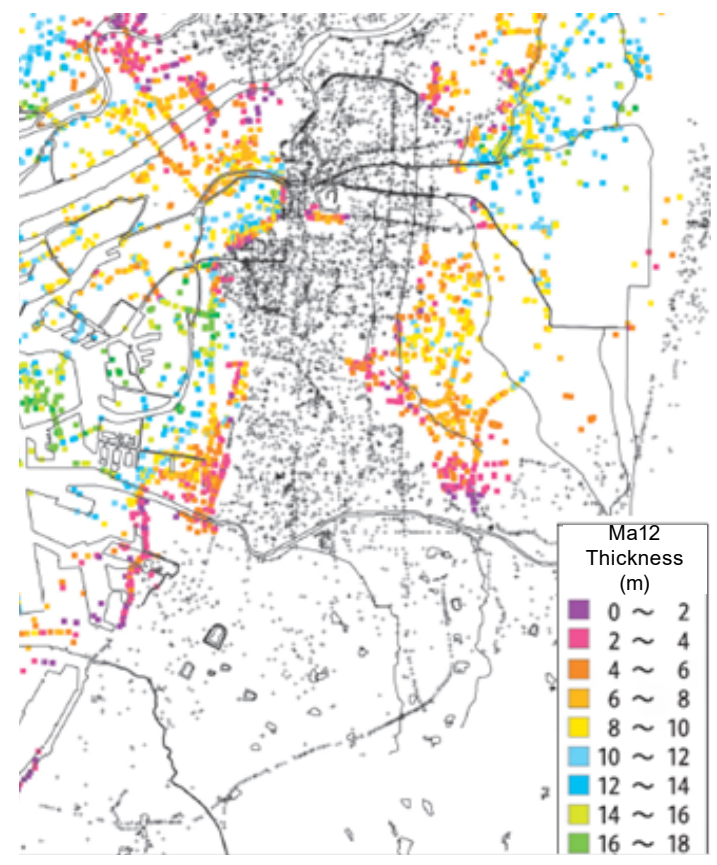

Figure 9. Thickness of Ma12 


\section{Architecture and Engineering Volume 3 Issue 2}

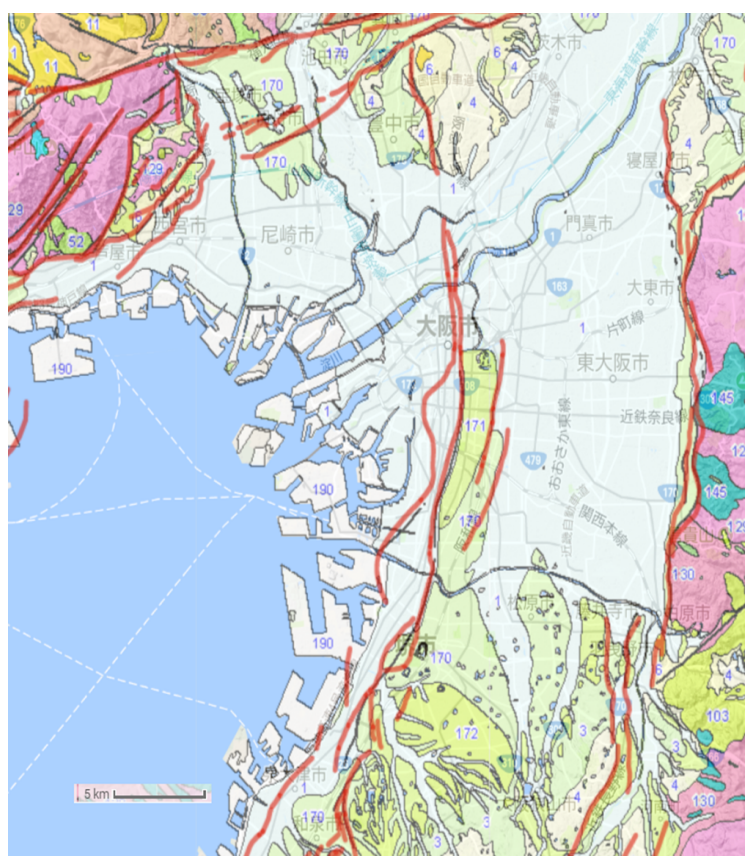

Figure 10. Active faults in Osaka (Geological Survey of Japan as of 2018)

Areal distribution of the thickness of Ma13 and Ma12 are shown in Figure 8 and 9. The thickness of Ma13 in Figure 8 is around $10-14 \mathrm{~m}$ in the western Osaka and decreases with eastwards and disappears at the west edge of the Uemachi terrace along the Uemachi fault. The thickness of Ma12 in Figure 9 is about $6-10 \mathrm{~m}$ in the western area in Osaka and then decreases towards east just like as Ma13. The difference is the disappearing shape of these geological formations. The shape of disappearing of Ma13 is rather straight line, but that of Ma12 is concaved curve.

The detailed study has revealed that the curvature is caused by another active fault structure named as "Sakuragawa Flexure".

Osaka 1-Line is in east-west direction at the south of the Osaka area, where several active faults are being crossed over. These active faults were estimated by geomorphological feature of the surface of the ground of the terrace and/or steps along the faults. The reflection image of Osaka 1-Line shows only continuous deformation of sedimentary layers with inclination towards to the east.

The base rock is clearly recorded by the survey and is shown at the GL-1,000m to $1,300 \mathrm{~m}$. The shape of the image does not show any fault gap of the displacement along the line, which contradicts the existence of the faults indicated by the geological survey of Japan. The faults in Osaka area are not strike slip with any vertical displacement but reversal dip slip with some vertical slip component.

The fault lines have been estimated by topological features of straight lines with vertical steps for some

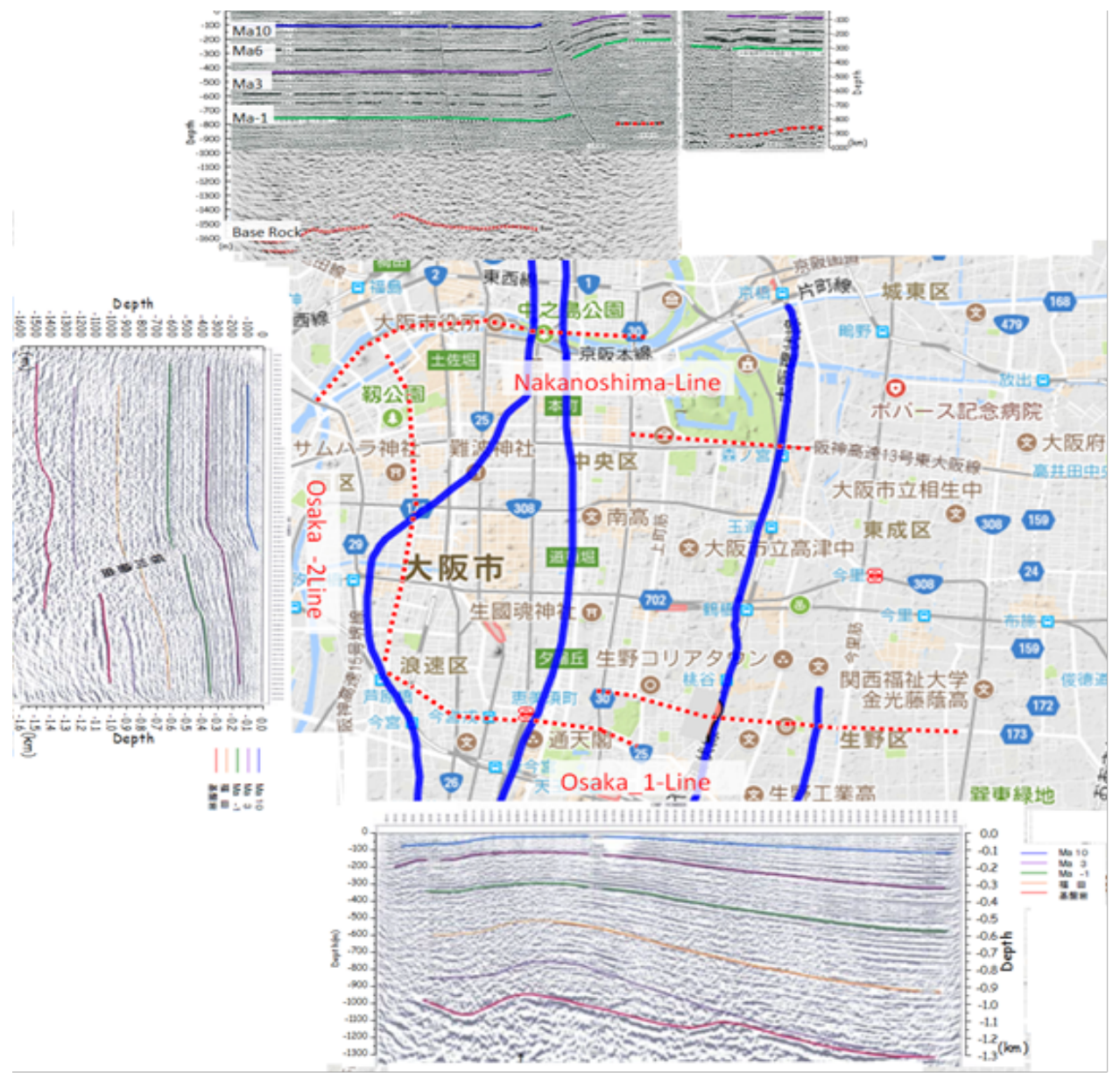

Figure 11. Seismic reflection results in Osaka 
continuous distance. However, the estimated faults should be re-evaluated and deleted at least beneath the survey line.

It may be clear that the "fault that is estimated by the characteristic elements of ground surface of fault" is not necessary to provide the correct information of fault existence.

Osaka 2-Line is in north-south direction at the west of the Osaka city, where the ground surface is flat and horizontal. The fault line was estimated by the boring data that show stepwise formation of underground layers.

The seismic reflection of Osaka 2-Line shows the clear fault structure of different depths of the rock. The depths of rock at the north and south sides are $1,500 \mathrm{~m}$ and $1,000 \mathrm{~m}$.

\section{Subway lines and faults in Osaka}

At present in 2018, Geological Survey of Japan shows tectonic active faults as in Figure 10. Figure 11 shows some comparison between the active faults by Geological Survey of Japan(GSJ) in blue lines and seismic reflection results. It is found the estimated faults by GSJ do not correspond with the reflection survey. For an example, reflection line Osaka-1 show no deformation at four points where it crosses with the expected faults. We need to study more detailed structure to clarify the fault systems in Osaka.

Lifeline system and active faults

Subway metro is one of the important lifelines in urban area.

Figure 12 shows active fault lines and subway lines and indicates crossing points of the faults and subway lines. Figure 13 shows the distribution of boring points in the area and the selected zone along the subway line in the Figure 12. Figure 14 shows the characterization of fault movements as the flexure of two parameters.

The vertical displacement and the width of the fault as dip $=30 \mathrm{~m}$ and width $=600 \mathrm{~m}$ respectively.

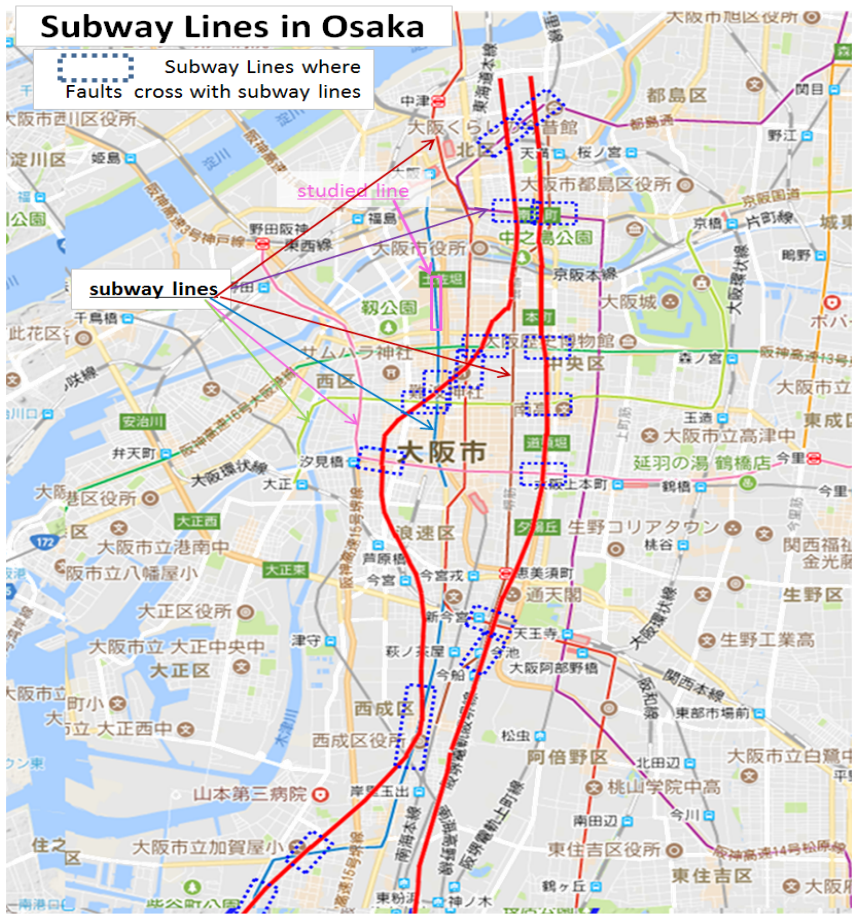

Figure 12. Subway lines in Osaka

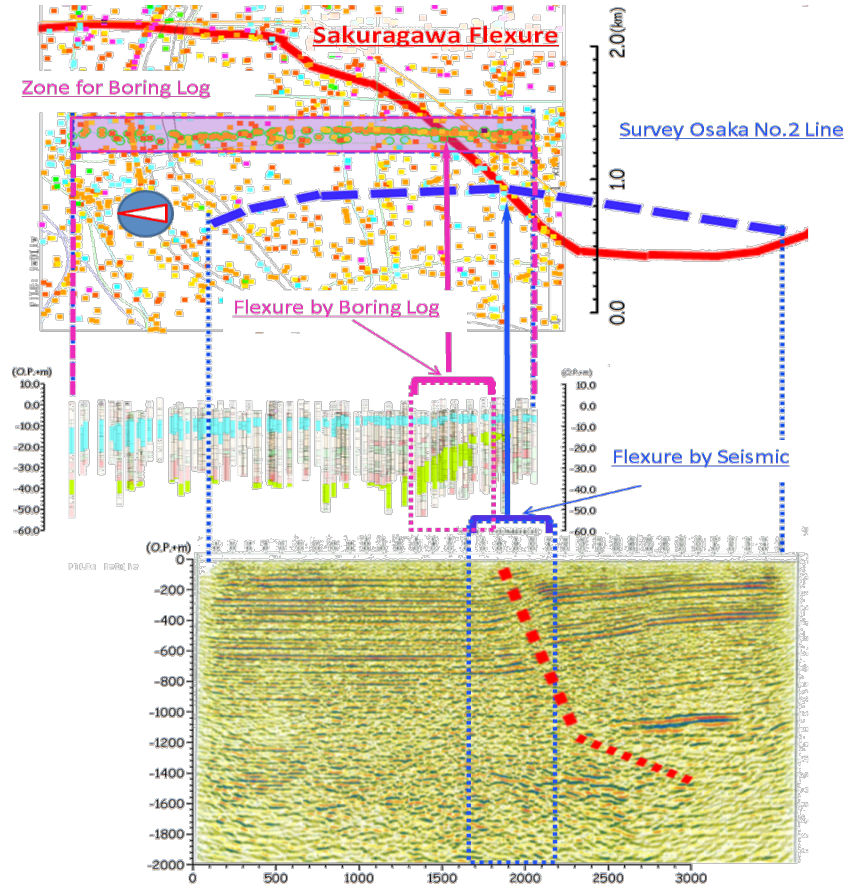

Figure 13. Boring data base along the studied line in Figure 12

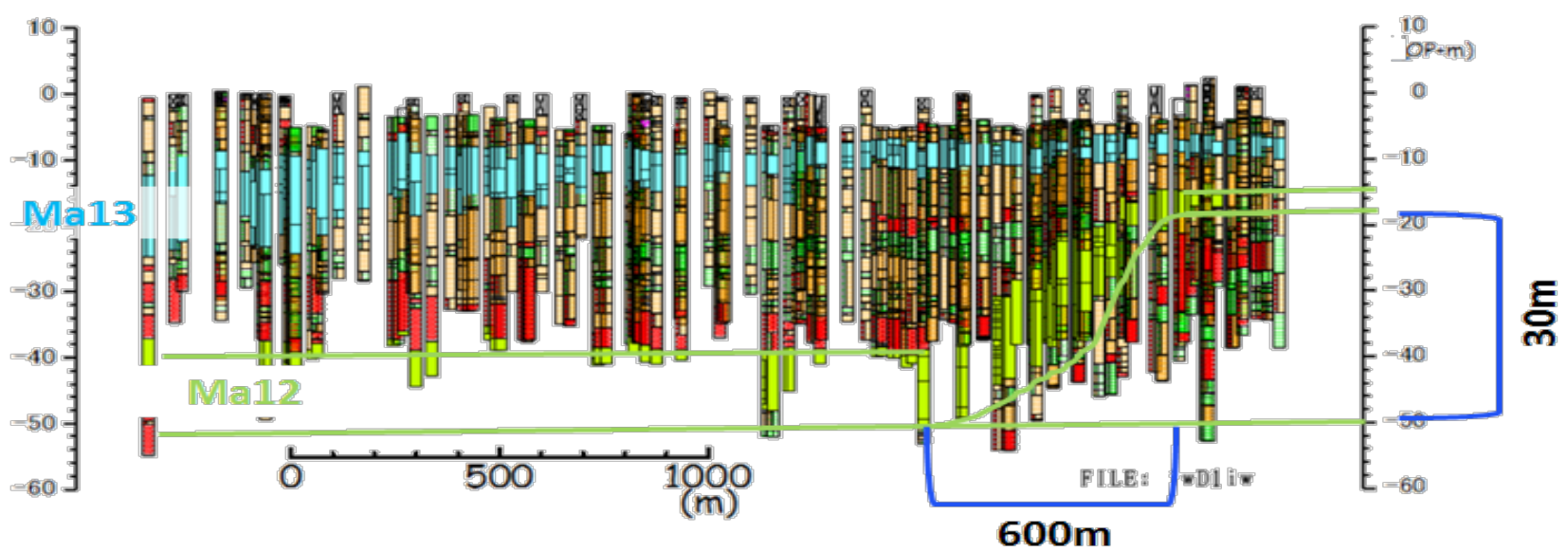

Figure 14. Characterization of the Fault movement of Ma12 


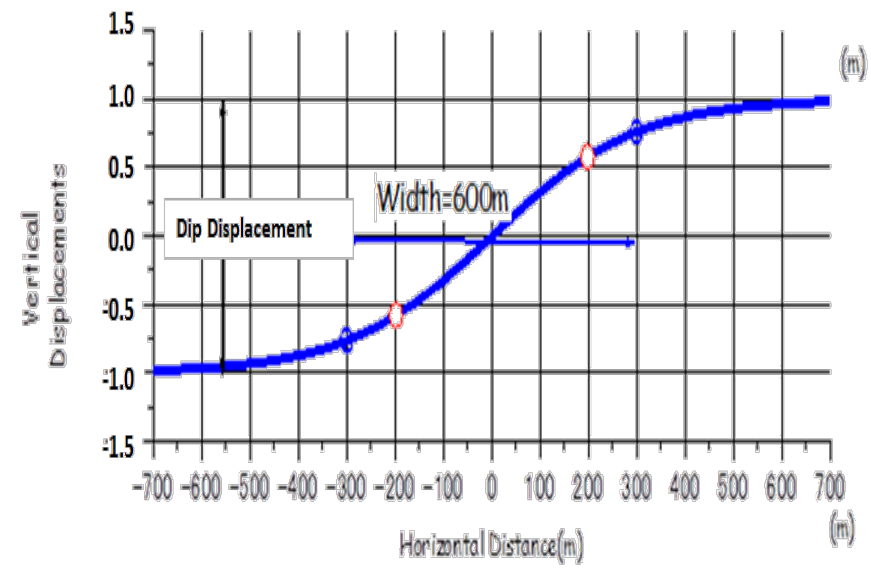

Figure 15. Anticipated deformation of the fault

The Ma12 is considered as the deposition during the geological period of 130,000 years before the present.

The anticipated deformation of the surface ground is shown in Figure 15.

Several important aspects of the fault displacements to the life line structure are 1 inclination, 2 flexure moments, 3 tension and compression strains caused by flexure mode of displacement, and overall compression strain caused by reverse fault.

The geological period of deposit of Ma12 is the late quaternary of around 120,000 to 130,000 of the sea water level near the present level as shown in Figure 6 of the change of the sea water level with the time of global climate history. The return period of the fault activity is estimated about 10,000 years, which results in 12 times of fault movements.

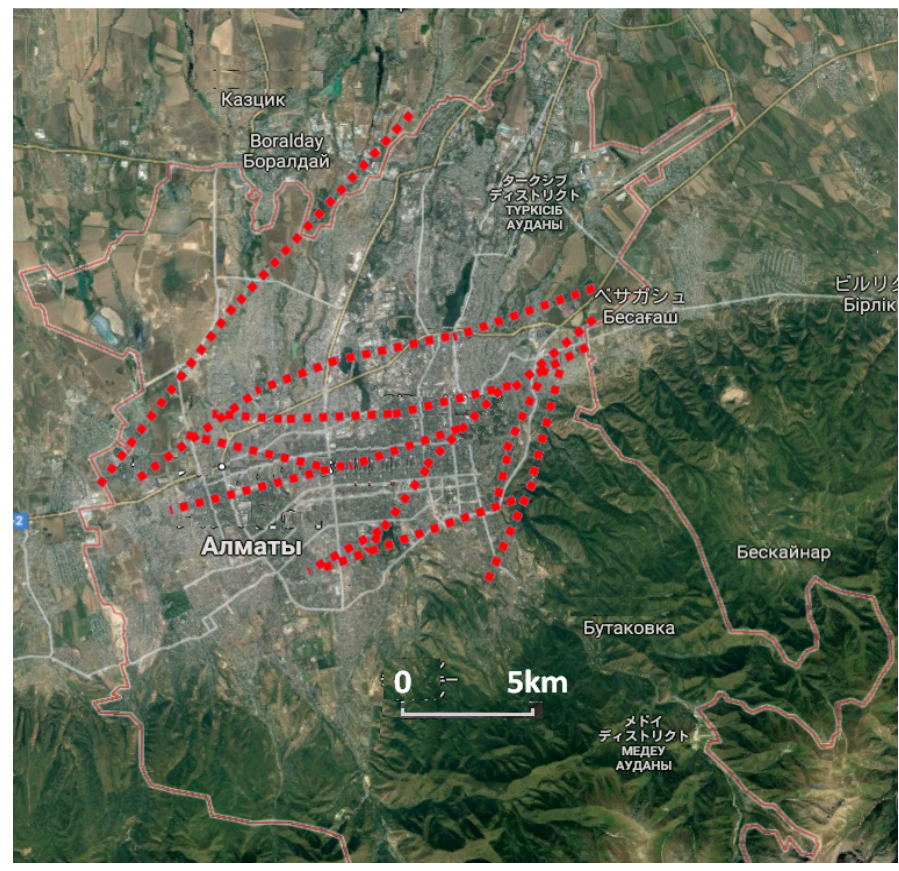

Figure 16. Fault Lines in Almaty (JICA (2009))

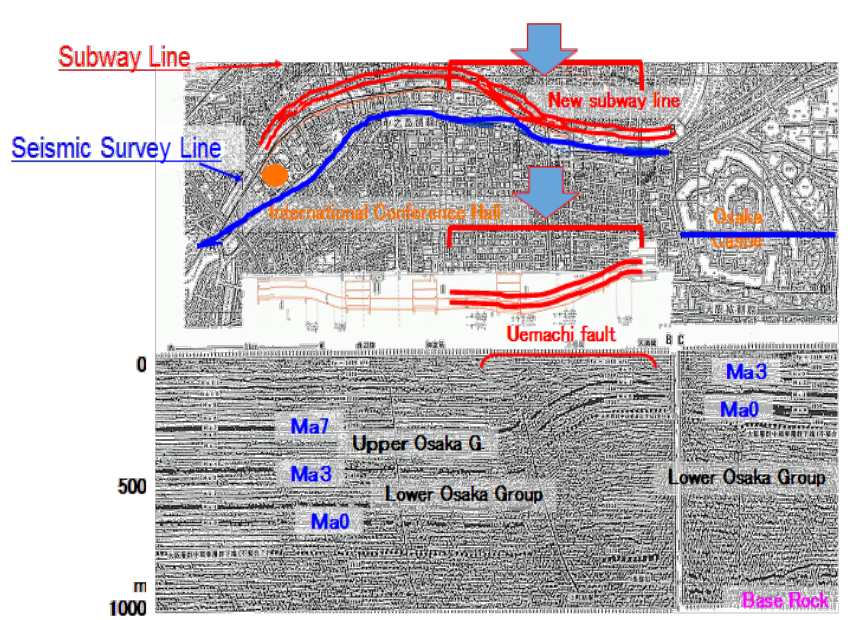

Figure 17. Section and Plan for subway extension of Keihan Line

The maximum vertical displacement for one fault movement is estimated by dividing the total displacement of $30 \mathrm{~m}$ by 12 , which results in about $2.5 \mathrm{~m}$ for the next earthquake displacement.

\section{Aseismic Design for Subway line in Osaka}

When a subway extension of about $2.9 \mathrm{~km}$ from Tenmabashi to the west wards that crosses over the active fault, the anticipated displacement by the fault movement was applied to design the tunnel structure as aseismic capability.

Due to the bending deformation that is anticipated during the fault movement, the concrete segment of the shield tunnel was changed to the ductile steel segment was selected to protect the subway from the collapse of the train as the subway during Kobe Earthquake of 1995.

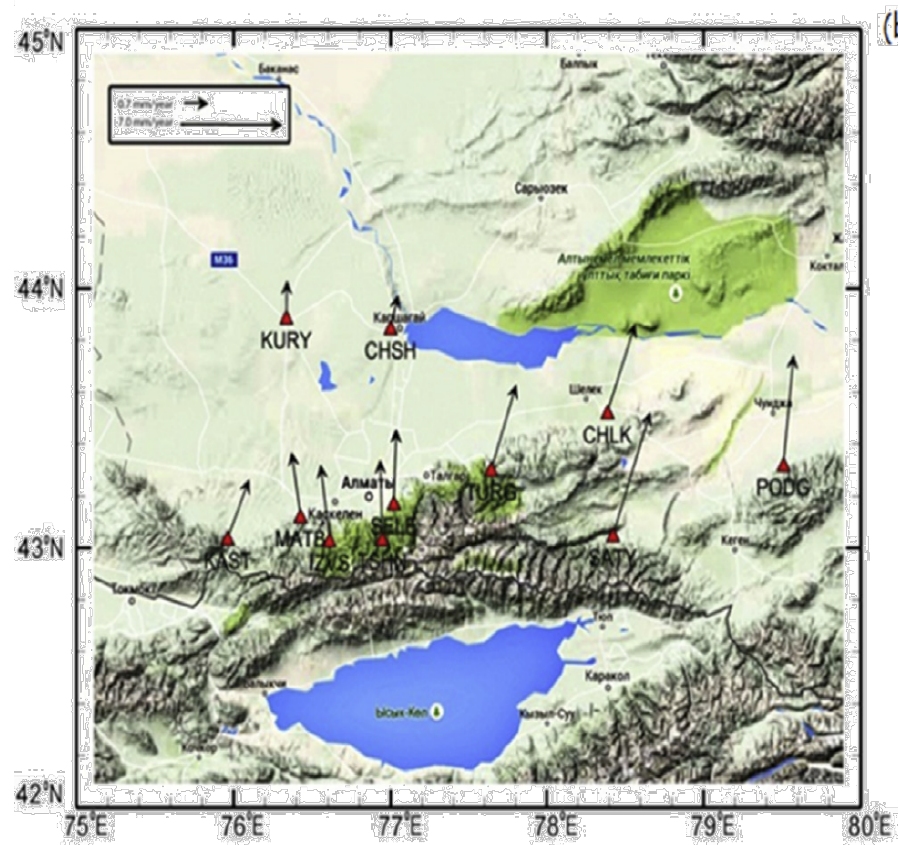

Figure 18. Crustal velocity by GPS monitoring (Vilaev (2017)) 


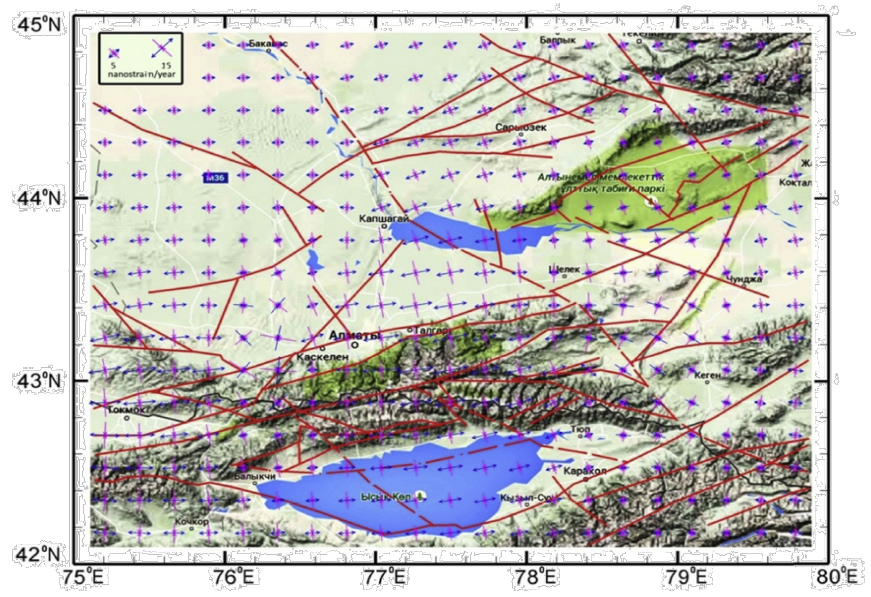

Figure 19. Distribution of ground strains in horizontal direction (Vilaev (2017))

\begin{tabular}{|c|l|l|}
\hline Fmo & Fine-grained soil (high organic) & \\
\hline Fms & Fine-grained soil (soft ground) & \\
\hline Fma & Fine-grained soil & \\
\hline Sa & Sand & \\
\hline Ga & Gravel & \\
\hline Gr(w) & Weathered granite & \\
\hline Gr & Granlte & \\
\hline
\end{tabular}

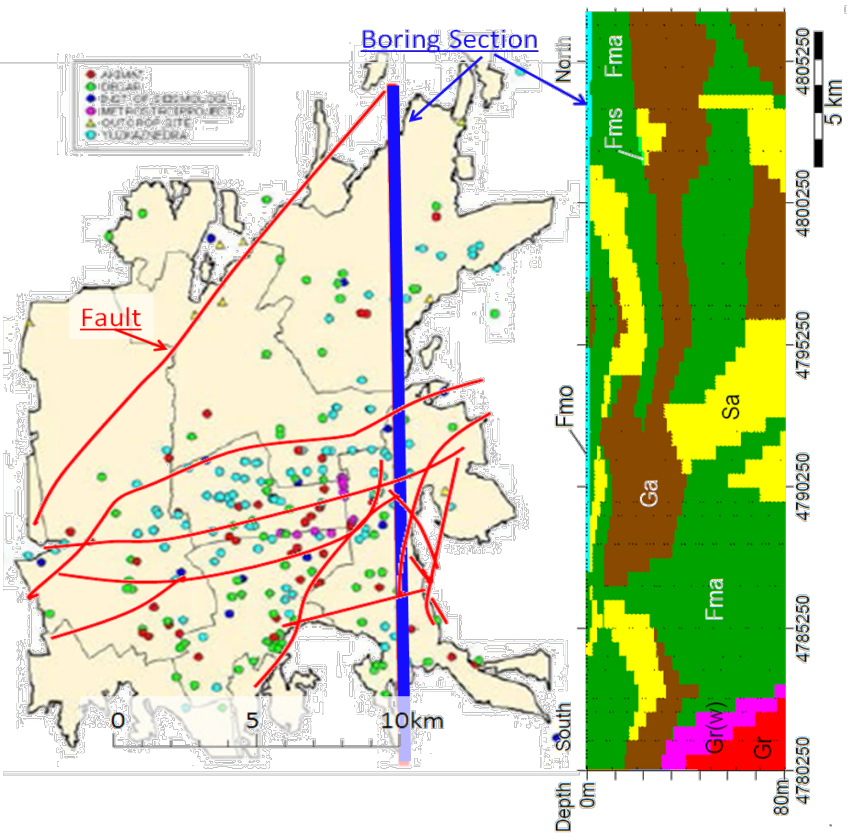

Figure 20. Example of geological section in Almaty

\section{Active Faults in Almaty, Kazakhstan}

The active faults in Almaty in Kazakhstan were studied by geomorphological character of the surface topology and shown as in Figure 17. Almaty area is located at the north of the Tien Shen Mountain that is tectonically very active being pushed by Indian continent.

As shown in Figure 18, GPS monitoring shows GPS movements in Almaty shows northwards displacement of about $7 \mathrm{~mm} /$ year, which results in compression strain in NS and expansion strain in EW direction that shall induce the reverse type of fault plane in EW direction as well

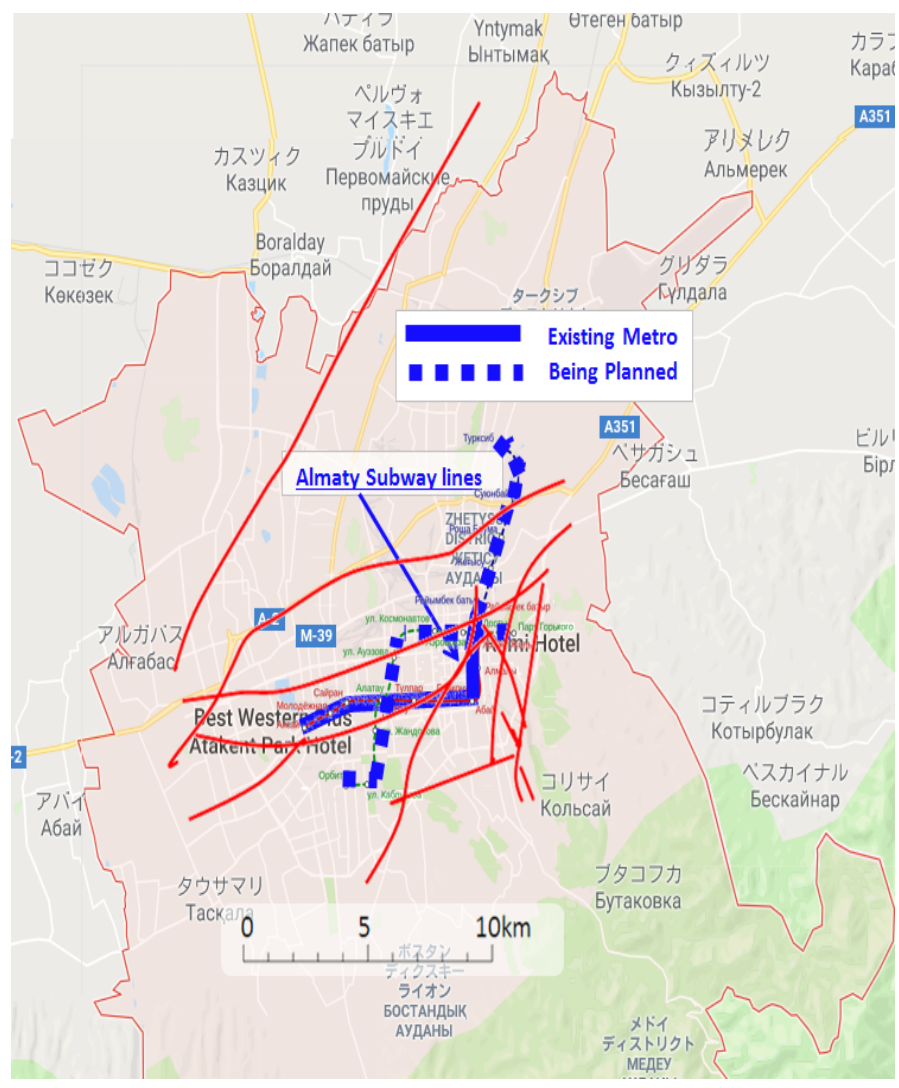

Figure 21. Subway system and fault lines in Almaty

as strike slip type of fault plane in about E30N or E120N direction. The fault directions in Figure 17 are consistent with what is expected by Figure 19.

JICA provided study of prediction of earthquake damage in Almaty and JICA made a study ground condition based upon boring data in Almaty and showed vertical section along NS direction as shown in Figure 20. The vertical section shows rather complicated structure than simple multi-layer.

JICA provided fundamental information of earthquake problems for Almaty. However, JICA did not study the long period problem caused by the very thick deposit of 3-4 km of the Almaty area and ground displacement effects from active fault.

\section{Subway lines and active faults in Almaty}

Figure 21 shows the subway system in Almaty as well as the anticipated active faults lines. The solid line for subway is under operation at present and the dotted line is being planned in the future.

The subway plan has been never considered the effects of the active faults in Almaty, which is rather common practice in the world. However, the professional people, especially the geotechnical engineers must give the information to the society on the situation of the present weak points of the preparedness for earthquake disasters.

Geotechnical engineering warning of dangerous situation and share the knowledge on the faults, develop preventive countermeasures to protect the people in Almaty. 


\section{Architecture and Engineering Volume 3 Issue 2}

\section{Conclusions}

Active fault system in Osaka based upon boring data system as well as seismic reflection is presented. Faults problems of Almaty in Kazakhstan, where active faults might result in severe disaster, are reviewed.

In Osaka area, geotechnical knowledge has been utilized to identify the position and characteristics of the ground deformation by the active faults. In Almaty, geotechnical boring logs should be compiled as the fundamental data base to provide very basic geological setting, ground zoning, including fault structures.
As shown for predicted active fault based upon only surface geomorphology does not necessary true, the underground structures should be confirmed by such survey of seismic reflection and/or geological borings.

Almaty is the most dangerous situation among three cities.

Geotechnical engineers in Kazakh should initiate the study of active fault and provide the damage potential and as well as effective countermeasures to protect the 1.5 million citizens in Almaty and to create resilient city for Kazakh. 


\section{References}

Gonzaleza, D.P., Monsalve, M., Moris, R., Herrer, C. (2018). Risk and Resilience Monitor: Development of multiscale and multilevel indicators for disaster risk management for the communes and urban areas of Chile. Applied Geography, 94, pp. 262-271. DOI: 10.1016/j.apgeog.2018.03.004

JICA (2009). The study on earthquake disaster risk management for Almaty City in the Republic of Kazakhstan: final report, vol. 2. Main report 1: evaluation of earthquake hazards and risks in Almaty City.

Kamiya, N., Yamamoto, Y., Wang, Q., Kurimoto, Y., Zhang, F., Takemura, T. (2017). Major variations in vitrinite reflectance and consolidation characteristics within a post-middle Miocene forearc basin, central Japan: A geodynamical implication for basin evolution. Tectonophysics, 710-711, pp. 69-80. DOI: 10.1016/j.tecto.2016.10.027

Mili, R.R., Hosseini, K.A., Izadkhah, Y.O. (2018). Developing a holistic model for earthquake risk assessment and disaster management interventions in urban fabrics. International Journal of Disaster Risk Reduction, 27, p. 355-365. DOI: 10.1016/j. ijdrr.2017.10.022

Lobkovsky, L.I. (2016). Deformable plate tectonics and regional geodynamic model of the Arctic region and Northeastern Asia. Russian Geology and Geophysics, 57 (3), pp. 371-386. DOI: 10.1016/j.rgg.2016.03.002

Parsizadeha, F., Ibrion, M., Mokhtaric, M., Lein, H., Nadim, F. (2015). Bam 2003 earthquake disaster: On the earthquake risk perception, resilience and earthquake culture - Cultural beliefs and cultural landscape of Qanats, gardens of Khorma trees and Argh-e Bam. International Journal of Disaster Risk Reduction, 14 (4), pp.0 457-469. DOI: 10.1016/j.ijdrr.2015.09.011

Stolbikhin, lu.V., Fedorov, S.V., Kudryavtsev, A.V. (2018). Reconstruction of the sewage treatment plant using "geo-containers". Water and Ecology, 1, pp. 31-38. DOI: 10.23968/2305-3488.2018.23.1.31-38

Vilayev, A.V., Zhantayev, Zh.Sh., Bibosinov, A.Zh. (2017). Monitoring crustal movements in northern Tianshan Mountain based on GPS technology. Geodesy and Geodynamics, 8(3), pp. 155-159. DOI: 10.1016/j.geog.2017.03.006

Zhantayev, Z., Bibossinov, A., Fremd, A., Talgarbayeva, D., Kikkarina, A. (2017). Automated lineament analysis to assess the geodynamic activity areas. Procedia Computer Science, 121, pp. 699-706. DOI: 10.1016/j.procs.2017.11.091 